\title{
The Effect of Parents' Attention on the Technology Usage of Children between the Ages of Four and Six
}

\section{Dazim Biber ${ }^{1}$ \\ iD Ayşe Nur Kayiş ${ }^{2}$ \\ Mehriye Kopuk ${ }^{3}$ \\ Şeyma Dağdeviren ${ }^{4}$}

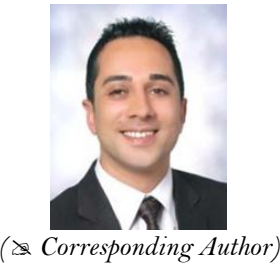

${ }^{\prime}$ Balikesir University, Faculty of Education, Department of Elementary Education, The Head of Preschool Education Division, Turkey.

${ }^{2}$ Email:kazimbiber@hotmail.com Tel:5056917825

${ }^{2,3,4}$ Balikesir University, Institute of Social Sciences, Department of Elementary Education, Turkey.

Tel: 5546610939

Tel: 5354919514

'Tel: 5459769755

\section{Abstract}

The aim of the study was to determine the technology usage characteristics of children between the ages of 4-6 and to determine whether these characteristics differ according to parental attention. This research is a relational screening model. The study group of the research consists of 117 children and their parents aged 4-6 years who attend independent kindergartens and kindergartens at elementary schools in Karesi and Altıeylül districts of Balıkesir province in 20182019 academic year. As data collection tool, "Personal Information Form" that includes demographics of children and their parents prepared by researchers, "Technology Use Questionnaire of Preschool Children of 4-6 Years" prepared by researchers, and "Parental Attention for Children Scale" that was developed by Campbell et al. (1986) and adapted by Sucuoglu et al. (2015) in order to determine parental attention for children were used. Descriptive analyses were performed, scale reliability was calculated, distribution of data was examined, and difference tests were applied depending on the distribution. In addition, one-way analysis of variance (ANOVA) post-hoc tests and independent samples t-test were used. In the Parental Attention for Children Scale, while there was a linear relationship between the mother and father forms and its sub-dimensions; there was a linear relationship between the level of "Attention for Control", a the sub-dimension of father form, and survey questions. Despite the high interest in control, it was observed that children's use of technology was high.

Keywords: Technology usage, Parental attention, Preschool, Child, Relational screening model, Kindergarten.

Citation | Kazım Biber; Ayşe Nur Kayiş; Mehriye Kopuk; Şeyma Dağdeviren (2019). The Effect of Parents' Attention on the Technology Usage of Children between the Ages of Four and Six. Asian Journal of Education and Training, 5(3): 473-481. History:

Received: 24 June 201

Revised: 31 July 2019

Accepted: 6 September 2019

Published: 9 October 2019

Licensed: This work is licensed under a Creative Commons Attribution 3.0 License $(\mathrm{cc}) \mathrm{EY}$

Publisher: Asian Online Journal Publishing Group
Acknowledgement: All authors contributed to the conception and design of the study.

Funding: This study received no specific financial support.

Competing Interests: The authors declare that they have no conflict of interests.

Transparency: The authors confirm that the manuscript is an honest, accurate, and transparent account of the study was reported; that no vital features of the study have been omitted; and that any discrepancies from the study as planned have been explained.

Ethical: This study follows all ethical practices during writing.

\section{Contents}

1. Introduction

475

3. Findings 477

4. Discussion, Conclusion and Suggestions 479

References. 


\section{Contribution of this paper to the literature}

This study contributes to the existing literature by determining the technology usage characteristics of children between the ages of 4-6 and to determine whether these characteristics differ according to parental attention.

\section{Introduction}

It is impossible to deny the fact that we live in a world dominated by technology. Today, children are born in a world where technology is deeply integrated into the fabric of everyday life. With every new technological idea, the world becomes a better place, information is reached faster, and new experiences are gained faster. Using technology in appropriate conditions and with appropriate software contributes positively to children's language, cognitive, physical, social, and emotional development (Akkoyunlu and Tugrul, 2002). "The Common Sense Census" report, prepared in the United States to demonstrate the use of children's media and technology in the 0-8 age range, was re-prepared in 2017 combining data from the 2011 and 2013 reports (Rasmussen, 2017). The report describes how media use of children aged 0-8 develops over time, and how technology can be used to support children's learning, plays, and games. Another striking part of this report is the answers to the question "How much time do children spend on screens?"

- American children between 0 and 8 years of age use an average of 2 hours and 19 minutes of screen per day.

- Children under the age of 2 spend about 42 minutes, children between the ages of 2 and 4 spend about 2 hours and 40 minutes, and children between the ages of 5 and 8 spend about 3 hours $(2: 58)$ on the screen during the day.

- In 2011 , children spent 4 percent of their screen time on one mobile device and this ratio increased to 35 percent in 2017.

- Nearly all children (98 percent) between the ages of 0 and 8 have a mobile device equal to TV in the house they live in.

Based on these statistics, the American Academy of Pediatrics recommends that children under 18 months do not use any screen media other than video chat and that children up to the age of 5 should be limited to one hour per day. In the Common Sense Census, it was concluded that American children spend more time with more screen media than recommended, and that most of this time is due to the fact that children can easily access mobile devices.

Today, technology is used in schools to support learning and increase motivation. In the research conducted by Steinhoff (2016) on how teachers use technology in pre-school education, it was found that $90 \%$ of teachers have access to technology in school and use them regularly, and $88 \%$ use technical devices at least once a week. In addition, the majority of teachers stated that they include computer or interactive whiteboards in their classes to improve the learning environment and to help them build stronger relationships with children on issues discussed in the classroom. Technology can give teachers the ability to design unique learning environments for children. Teachers can bring new resources to the classroom using technical devices and provide children with a much more interactive experience using online applications or exams. However, teachers need to have sufficient knowledge, skills, and equipment to use technology. In this period, where modern technologies are widely used for children both at home and in school, children are defined as active individuals called e-society based on digital connections.

Parental attention plays a critical role in entire school life. Parental attention can be defined as different behaviors and activities that involve the aims, aspirations, expectations, attitudes and beliefs of families regarding the education of the child at home or at school (Epstein, 1990; Hong and Ho, 2005; Georgiou and Tourva, 2007; Green and Hoover-Dempsey, 2007; Jeynes, 2007; Berthelsen and Walker, 2008; Smith et al., 2011; Shiffman, 2013). These behaviors and activities can be illustrated as reading books, magazines and so on; limiting watching television on school evenings; talking to the teacher about the child's development and behavior; attending schoolrelated activities (e.g., attending school-family reunions, conferences, trips); helping with homework assignments; and managing the child's time at home and away from home etc. (Green and Hoover-Dempsey, 2007; Berthelsen and Walker, 2008; Smith et al., 2011; Shiffman, 2013). Greenwood and Hickman (1991) in their study on parental attention and student variable at primary school level, indicated that parental attention had positive effects in many areas such as student's academic achievement, student's welfare feeling, responsibility for homework, and positive attitude in the classroom. However, the benefits of parenting and school involvement are not specific to primary school. Researchers have shown that parental attention in child and adolescent education contributes to children's learning and school achievement (Hoover-Dempsey and Sandler, 1997). Parents are the first educators of children, especially in the pre-school period where development is the fastest, and they support educational achievement and influence on learning (Henderson and Berla, 1994; Anderson and Minke, 2007; Berthelsen and Walker, 2008; Jeynes, 2011). The emotional traits, interests, and tendencies of the parents who are the first educators and role models of children affect their children directly or indirectly. For example, parents' reading habits are known to influence children's reading habits; also their interest and tendency in sports and the arts influence children's preferences. Similarly, the opportunities provided by families regarding the use of technology may also be effective in increasing children's awareness and tendency in this area from early ages (Akkoyunlu and Tugrul, 2002).

In the studies conducted, it was determined that mother attention starting from preschool was directly related to the educational success of the child in the future, and father attention had a long-term effect on the success of the child (Flouri and Buchanan, 2004; Berthelsen and Walker, 2008). However, it is not clear which components of parental attention and how much this component affect academic achievement (Fan, 2001; Smith et al., 2011). Today, when technology is rapidly spreading and consumed, parents and children spend most of their time using electronic media such as tablets, smartphones, computers, and television. While technology provides opportunities for parents and children to support education, entertainment, and development; it is also known there might be harmful effects of tablets, smartphones, computers, and the Internet that children have started to use in preschool period and widely used in adolescence in terms of physical and mental development of children. It is thought that 
as a result of the frequent use of technological devices such as mobile phones and tablets by children and parents, family communication and parent's attention toward child will be affected. Based on the data from the European Evidence Database in the Science and Policy report of the Joint Research Center of the European Union, it was emphasized that studies on the technology usage of children in Europe mostly covered the ages of 14 and 15 (close to 1000 studies), whereas less studies were conducted on 0-6 age groups (close to 200); and the role of parents in children's using new technologies did not receive much attention (Chaudron et al., 2015). From this point of view, it is the purpose of this study to determine whether the technology usage of children in today when the technology is widely used is differentiated according to the parents' attention toward their children.

\section{Method}

\subsection{Research Design}

This study, which aims to determine the technology usage of children between the ages of 4 and 6 in preschool period and compare them with the parents' attention toward their children, used the relational screening model (Büyüköztürk et al., 2012). Descriptive studies such as screening model aim to describe the present and past situations as they are. This model tries to define the subject of the research as it is and does not try to change it Karasar (2005).

\subsection{Research Sample}

The study group of the research consists of 117 children and their parents aged 4-6 years who attend independent kindergartens and kindergartens at elementary schools in Karesi and Altıeylül districts of Balıkesir province in 2018-2019 academic year. The demographics of the study group are given in Table 1, Table 2, Table 3, and Table 4.

Table-1. Demographics of the study group.

\begin{tabular}{c|c|c}
\hline & Frequency $(\boldsymbol{f})$ & Percentage (\%) \\
\hline Gender & & 54.0 \\
\hline Female & 63 & 46.0 \\
\hline Male & 54 & 10.25 \\
\hline Birth year & & 83.77 \\
\hline 2012 & 12 & 5.98 \\
\hline 2013 & 98 & 11.12 \\
\hline 2014 & 7 & 48.71 \\
\hline Number of siblings & & 29.05 \\
\hline 0 & 13 & 11.12 \\
\hline 1 & 57 & 64.1 \\
\hline 2 & 34 & 35.9 \\
\hline 3 & 13 & \\
\hline Private room & & 9.98 \\
\hline Yes & 75 & \\
\hline No & 42 &
\end{tabular}

Table-2. Mothers' demographics of the study group.

\begin{tabular}{|c|c|c|}
\hline & Frequency $(f)$ & Percentage (\%) \\
\hline \multicolumn{3}{|l|}{ Mother } \\
\hline Alive & 117 & 100.0 \\
\hline \multicolumn{3}{|l|}{ Mother } \\
\hline Own mother & 117 & 100.0 \\
\hline \multicolumn{3}{|l|}{ Mother } \\
\hline Together & 116 & 99.14 \\
\hline Separated & 1 & .86 \\
\hline \multicolumn{3}{|l|}{ Education status } \\
\hline Not educated & 3 & 2.58 \\
\hline Literate & 1 & .86 \\
\hline Primary school & 34 & 29.05 \\
\hline Middle school & 23 & 19.65 \\
\hline High school & 37 & 31.62 \\
\hline College & 7 & 5.98 \\
\hline University & 10 & 8.54 \\
\hline Masters and above & 2 & 1.72 \\
\hline \multicolumn{3}{|l|}{ Job } \\
\hline Housewife & 84 & 71.79 \\
\hline Officer & 10 & 8.54 \\
\hline Worker & 9 & 7.7 \\
\hline Others & 14 & 11.97 \\
\hline \multicolumn{3}{|l|}{ Disabled status } \\
\hline Yes & 3 & 2.58 \\
\hline No & 114 & 97.42 \\
\hline \multicolumn{3}{|l|}{ Socioeconomic level } \\
\hline Lower & 18 & 15.38 \\
\hline Average & 99 & 84.62 \\
\hline
\end{tabular}


As can be seen in Table 1, 54\% of preschool children in the ages of 4-6 were females and 46\% were males. Children born in 2013 constituted approximately $84 \%$ of the study group. While $48.71 \%$ of the children had 1 sibling, $11.12 \%$ had no siblings. 75 children had their own rooms and 42 children did not have their own rooms. $5.98 \%$ of children had a health issue of unknown type.

All mothers of the children in the study group were alive and children's own mothers. Only 1 of the children had separate parents. Approximately $30 \%$ of mothers were primary school graduates, while $2.58 \%$ were illiterate. 84 mothers were housewives, 10 mothers were officers, and 9 mothers were workers. $97.42 \%$ of the mothers were not disabled. While 18 mothers perceive themselves at lower socioeconomic level, 99 mothers regard themselves at average socioeconomic level.

Table-3. Fathers' demographics of the study group.

\begin{tabular}{|c|c|c|}
\hline & Frequency $(f)$ & Percentage (\%) \\
\hline \multicolumn{3}{|l|}{ Father } \\
\hline Alive & 117 & 100.0 \\
\hline \multicolumn{3}{|l|}{ Baba } \\
\hline Own father & 117 & 100.0 \\
\hline \multicolumn{3}{|l|}{ Father } \\
\hline Together & 116 & 99.14 \\
\hline Separate & 1 & .86 \\
\hline \multicolumn{3}{|l|}{ Education status } \\
\hline Not educated & 1 & .86 \\
\hline Literate & 1 & .86 \\
\hline Primary school & 20 & 17.08 \\
\hline Middle school & 26 & 22.22 \\
\hline High school & 39 & 33.32 \\
\hline College & 13 & 11.12 \\
\hline University & 15 & 12.82 \\
\hline Masters and above & 2 & 1.72 \\
\hline \multicolumn{3}{|l|}{ Job } \\
\hline Officer & 23 & 19.66 \\
\hline Worker & 44 & 37.6 \\
\hline Unemployed & 2 & 1.72 \\
\hline Others & 48 & 41.02 \\
\hline \multicolumn{3}{|l|}{ Disabled status } \\
\hline Yes & 4 & 3.3 \\
\hline No & 113 & 96.7 \\
\hline \multicolumn{3}{|l|}{ Socioeconomic level } \\
\hline Lower & 13 & 11.12 \\
\hline Average & 103 & 88.02 \\
\hline Upper & 1 & .86 \\
\hline
\end{tabular}

All fathers of the children in the study group were alive and children's own fathers. One of the children had separate parents. $22.22 \%$ of the fathers were middle school, $33.32 \%$ were high school, $12.82 \%$ were university, and $1.72 \%$ were masters and above graduates. While 23 fathers were officers, 44 fathers were workers, 48 fathers worked in other occupational groups. 96.7\% of the fathers were not disabled. 13 (11,12\%) fathers saw themselves at lower socioeconomic level, $103(88,02 \%)$ fathers at average socioeconomic level, and $1(0.86 \%)$ father at upper socioeconomic level.

Table-4. Other demographics of the study group.

\begin{tabular}{c|c|c}
\hline & Frequency $(\boldsymbol{f})$ & Percentage $(\%)$ \\
\hline House & & \\
\hline Rental & 51 & 43.59 \\
\hline Not rental & 66 & 56.41 \\
\hline Other people in the house & & 4.27 \\
\hline Yes & 5 & 95.73 \\
\hline No & 112 & \\
\hline Number of students in the house & & 39.32 \\
\hline 1 & 46 & 54.7 \\
\hline 2 & 64 & 5.98 \\
\hline 3 & 7 &
\end{tabular}

As shown in Table 4, 51 (43.59\%) families live in rental houses. While $5(4.27 \%)$ of the children in the study group shared their homes with individuals outside the family, 112 (95.73\%) lived only with family members. $39.32 \%$ of the families had 1 child, $54.7 \%$ had 2 children, and $5.98 \%$ had 3 children who continue their education.

\subsection{Data Collection Tools}

In the first part of the study, Personal Information Form that includes demographics of children and their parents was used as data collection tool. In the second part, the questionnaire form prepared by the researchers was used to determine the duration of technology usage of children, whether children use technological tools while eating, and finally to determine the reaction of children when using technological tools is not allowed. In order to determine the parental attention for children, Parental Attention Scale for Children Scale that was developed by Campbell et al. (1986) and adapted by Sucuoglu et al. (2015) was used. The Maternal Attention Scale consists a total of 34 items and 4 factors including "attention for control" (13 items), "attention for behavior development" (11 
items), "attention for school" (7 items), and "attention for improving interest" (3 items). The Paternal Attention Scale consists a total of 40 items and 3 factors including "attention for control" (11 items), "attention for behavior development" (16 items), and "attention for school" (13 items). Likert-type grading was used as " $1=$ Never", " $2=$ Rarely", " 3 = Sometimes", " $4=$ Frequently" and " $5=$ Very Frequently". The reliability coefficients of the Parental Attention for Children Scale are given in Table 5.

Table-5. Factors and Cronbach's $\alpha$ coefficients of the parental attention for children scale.

\begin{tabular}{|c|c|c|c|}
\hline & & \multicolumn{2}{|c|}{$\alpha$ Value } \\
\hline & & Factors & Overall scale \\
\hline \multirow{4}{*}{ Mothers } & Attention for control & .77 & \multirow{4}{*}{.89} \\
\hline & Attention for behavior development & .84 & \\
\hline & Attention for school & .80 & \\
\hline & Attention for improving interest & .81 & \\
\hline \multirow{3}{*}{ Fathers } & Attention for control & .93 & \multirow{3}{*}{.96} \\
\hline & Attention for behavior development & .94 & \\
\hline & Attention for school & .89 & \\
\hline
\end{tabular}

As shown in Table 5, the reliability coefficients of the scale and its sub-dimensions were calculated. Internal consistency coefficients of Maternal Attention Scale were .77 for attention for control, .84 for attention for behavior development, .80 for attention for school, .81 for attention for improving interest, and .89 for the whole scale. In the Father Attention Scale, internal consistency coefficients were .93 for attention for control, .94 for attention for behavior development, .89 for attention for school, and .96 for the whole scale. It was concluded that the questionnaires were reliable because the $\alpha$ coefficients of the scale validity were above .70 (Büyüköztürk, 2006).

\subsection{Data Analysis}

Mean, mode, median, skewness and kurtosis values of the study variables were calculated. If the mean, mode and median values are equal in a frequency distribution of a data set, we can say that the data is distributed symmetrically around the central tendency measures. In cases where these values are not equal to each other, it can be judged by looking at the skewness and kurtosis values. The fact that skewness and kurtosis coefficients are within the range of $(+1$ and -1$)$ shows that the data exhibits normal distribution (Büyüköztürk, 2006). The normality tests of the Parental Attention for Children Scale are given in Table 6.

\begin{tabular}{c|l|c|c|c|c|c}
\multicolumn{7}{c}{ Table-6. Normality tests of the parental attention for children scale. } \\
\hline & \multicolumn{2}{|c|}{ Mean } & Mod & Median & Skewness & \multicolumn{1}{c}{ Kurtosis } \\
\hline \multirow{4}{*}{ Mothers } & Attention for control & 3.51 & 3.85 & 3.54 & -.388 & -.916 \\
\cline { 2 - 7 } & Attention for behavior development & 3.44 & 4.00 & 3.55 & -.769 & .193 \\
\cline { 2 - 7 } & Attention for school & 2.46 & 2.43 & 2.43 & -.070 & -.722 \\
\cline { 2 - 7 } & Attention for improving interest & 2.64 & 2.67 & 2.67 & -.636 & .423 \\
\hline \multirow{3}{*}{ Fathers } & Attention for control & 2.92 & 2.75 & 3.00 & -.425 & -.208 \\
\cline { 2 - 7 } & Attention for behavior development & 3.08 & 3.36 & 3.18 & -.490 & -.325 \\
\cline { 2 - 7 } & Attention for school & 1.61 & 2.00 & 1.62 & .306 & -.214 \\
\hline
\end{tabular}

\section{Findings}

In this part of the research, the findings of the analysis are presented. Table 7 shows the results of one-way analysis of variance test conducted to determine whether the level of attention of parents for their children varies according to the duration of technology usage.

As can be seen in Table 7, the attention levels of the parents do not vary according to the duration of technology usage based on the one-way analysis of variance test conducted to determine whether the level of attention of parents for their children varies according to the duration of technology usage.

When the Table 8 was examined, it was found that there was a statistically significant difference between the mean scores of fathers' attention for behavior development and attention for control at the $\mathrm{p}<.05$ level based on the independent samples $t$ test to determine whether the parents' attention levels differ according to whether their children use technological tools while eating. When the average scores are considered, it is observed that this difference is in favor of children who do not use technological tools. It can be said that the effect of this variable on this differentiation is moderate.

According to the results of the independent group $t$ test to determine whether the participants 'level of interest differs according to the reaction of their children when the use of technological tools is not allowed, the mean scores of fathers' interest in behavior development, interest in control, and interest in school are significant Table 9. There was a statistically significant difference. When the average scores are examined, it is observed that this difference is in favor of the fathers of the children who show positive behavior. It can be said that the effect of this variable on this differentiation is moderate Table 11.

Mothers' level of attention for control was linearly related to mothers' other attention levels, fathers' level of attention for behavior development, and fathers' level of attention for control; and was inversely related to s3 (behavior score and duration of use; Table 10). Mothers' level of attention for behavior development was linearly related to mothers and fathers' other attention levels; and was inversely related to s3. The mothers' level of attention for school and their level of attention for improving interest were linearly related to mothers and fathers' other attention levels. 
Table-7. Results of one-way analysis of variance test.

\begin{tabular}{|c|c|c|c|c|c|c|c|c|c|c|c|}
\hline \multirow[t]{2}{*}{ Factors } & & & & & & \multicolumn{5}{|c|}{ ANOVA results } & \multirow[b]{2}{*}{ Effect size } \\
\hline & Group & $\mathbf{N}$ & $\overline{\mathbf{X}}$ & sd & Source of var. & SS & df & MS & $\mathbf{F}$ & p & \\
\hline \multirow[t]{5}{*}{ MAFC } & $<1$ hour & 17 & 3.63 & .31 & Between groups & 0.765 & 3 & 0.255 & \multirow[t]{4}{*}{2.18} & \multirow[t]{4}{*}{0.094} & \\
\hline & 1-2 hour & 55 & 3.52 & .36 & Within groups & 13.212 & 113 & 0.117 & & & \\
\hline & 2-3 hour & 30 & 3.50 & .32 & Total & 13.977 & 116 & & & & \\
\hline & 3-4 hour & 15 & 3.33 & .33 & & & & & & & \\
\hline & Total & 117 & 3.51 & .35 & & & & & & & \\
\hline \multirow[t]{5}{*}{ MAFBD } & $<1$ hour & 17 & 3.58 & .34 & Between groups & 1.195 & 3 & 0.398 & \multirow[t]{4}{*}{2.077} & \multirow[t]{4}{*}{0.107} & \\
\hline & 1-2 hour & 55 & 3.48 & .41 & Within groups & 21.669 & 113 & 0.192 & & & \\
\hline & 2-3 hour & 30 & 3.38 & .41 & Total & 22.863 & 116 & & & & \\
\hline & 3-4 hour & 15 & 3.22 & .65 & & & & & & & \\
\hline & Total & 117 & 3.44 & .44 & & & & & & & \\
\hline \multirow[t]{5}{*}{ MAFS } & $<1$ hour & 17 & 2.66 & .70 & Between groups & 2.596 & 3 & 0.865 & \multirow[t]{4}{*}{1.42} & \multirow[t]{4}{*}{0.241} & \\
\hline & $1-2$ hour & 55 & 2.51 & .83 & Within groups & 68.878 & 113 & 0.61 & & & \\
\hline & 2-3 hour & 30 & 2.43 & .72 & Total & 71.474 & 116 & & & & \\
\hline & 3-4 hour & 15 & 2.11 & .81 & & & & & & & \\
\hline & Total & 117 & 2.46 & .78 & & & & & & & \\
\hline \multirow[t]{5}{*}{ MAFII } & $<1$ hour & 17 & 2.94 & .77 & Between groups & 1.887 & 3 & 0.629 & \multirow[t]{4}{*}{0.769} & \multirow[t]{4}{*}{0.514} & \\
\hline & 1-2 hour & 55 & 2.59 & .99 & Within groups & 92.463 & 113 & 0.818 & & & \\
\hline & 2-3 hour & 30 & 2.61 & .92 & Total & 94.349 & 116 & & & & \\
\hline & 3-4 hour & 15 & 2.53 & .61 & & & & & & & \\
\hline & Total & 117 & 2.64 & .90 & & & & & & & \\
\hline \multirow[t]{5}{*}{ FAFBD } & $<1$ hour & 17 & 2.94 & .85 & Between groups & 0.011 & 3 & 0.004 & \multirow[t]{4}{*}{0.007} & \multirow[t]{4}{*}{0.999} & \\
\hline & $1-2$ hour & 55 & 2.91 & .77 & Within groups & 57.398 & 113 & 0.508 & & & \\
\hline & 2-3 hour & 30 & 2.92 & .50 & Total & 57.408 & 116 & & & & \\
\hline & 3-4 hour & 15 & 2.92 & .68 & & & & & & & \\
\hline & Total & 117 & 2.92 & .70 & & & & & & & \\
\hline \multirow[t]{5}{*}{ FAFC } & $<1$ hour & 17 & 3.06 & .75 & Between groups & 0.084 & 3 & 0.028 & \multirow[t]{4}{*}{0.068} & \multirow[t]{4}{*}{0.977} & \\
\hline & $1-2$ hour & 55 & 3.07 & .72 & Within groups & 46.874 & 113 & 0.415 & & & \\
\hline & 2-3 hour & 30 & 3.13 & .46 & Total & 46.958 & 116 & & & & \\
\hline & 3-4 hour & 15 & 3.06 & .53 & & & & & & & \\
\hline & Total & 117 & 3.08 & .64 & & & & & & & \\
\hline \multirow[t]{5}{*}{ FAFS } & $<1$ hour & 17 & 1.75 & .98 & Between groups & 0.451 & 3 & 0.15 & \multirow[t]{4}{*}{0.234} & \multirow[t]{4}{*}{0.872} & \\
\hline & $1-2$ hour & 55 & 1.60 & .83 & Within groups & 72.519 & 113 & 0.642 & & & \\
\hline & 2-3 hour & 30 & 1.59 & .69 & Total & 72.97 & 116 & & & & \\
\hline & 3-4 hour & 15 & 1.52 & .66 & & & & & & & \\
\hline & Total & 117 & 1.61 & .79 & & & & & & & \\
\hline
\end{tabular}

Table-8. Results of independent samples $t$ test to determine whether the parents' attention levels differed according to whether their children use technological tools while eating.

\begin{tabular}{|c|c|c|c|c|c|c|c|c|c|c|}
\hline \multirow[t]{2}{*}{ Factors } & \multirow[t]{2}{*}{ Groups } & \multirow[t]{2}{*}{$N$} & \multirow[t]{2}{*}{$\overline{\bar{X}}$} & \multirow[t]{2}{*}{ SS } & \multirow[t]{2}{*}{$\operatorname{Sh}_{\bar{X}}$} & \multicolumn{3}{|c|}{$t$ Test } & \multirow[t]{2}{*}{ Difference } & \multirow{2}{*}{$\begin{array}{c}\text { Effect size (Cohen's } \\
\text { d) }\end{array}$} \\
\hline & & & & & & $t$ & sd & $p$ & & \\
\hline \multirow{2}{*}{ MAFC } & Yes & 17 & 3.53 & 0.29 & .07 & \multirow{2}{*}{0.396} & \multirow{2}{*}{25.353} & \multirow{2}{*}{0.696} & & \\
\hline & $\mathrm{No}$ & 100 & 3.50 & 0.36 & .04 & & & & & \\
\hline \multirow{2}{*}{ MAFBD } & Yes & 17 & 3.41 & 0.36 & .09 & \multirow{2}{*}{-0.249} & \multirow{2}{*}{115} & \multirow{2}{*}{0.804} & & \\
\hline & $\mathrm{No}$ & 100 & 3.44 & 0.46 & .05 & & & & & \\
\hline \multirow{2}{*}{ MAFS } & Yes & 17 & 2.28 & 0.59 & .14 & \multirow{2}{*}{-1.04} & \multirow{2}{*}{115} & \multirow{2}{*}{0.300} & & \\
\hline & $\mathrm{No}$ & 100 & 2.49 & 0.81 & .08 & & & & & \\
\hline \multirow{2}{*}{ MAFII } & Yes & 17 & 2.86 & 0.89 & .22 & \multirow{2}{*}{1.112} & \multirow{2}{*}{115} & \multirow{2}{*}{0.269} & & \\
\hline & $\mathrm{No}$ & 100 & 2.60 & 0.90 & .09 & & & & & \\
\hline \multirow{2}{*}{ FAFBD } & Yes & 17 & 2.59 & 0.53 & .13 & \multirow{2}{*}{-2.103} & \multirow{2}{*}{115} & \multirow{2}{*}{0.038} & \multirow{2}{*}{$\mathrm{H}>\mathrm{E}$} & \multirow{2}{*}{.59} \\
\hline & No & 100 & 2.97 & 0.72 & .07 & & & & & \\
\hline \multirow{2}{*}{ FAFC } & Yes & 17 & 2.75 & 0.64 & .16 & \multirow{2}{*}{-2.346} & \multirow{2}{*}{115} & \multirow{2}{*}{0.021} & \multirow{2}{*}{$\mathrm{H}>\mathrm{E}$} & \\
\hline & $\mathrm{No}$ & 100 & 3.14 & 0.62 & .06 & & & & & .61 \\
\hline $\mathrm{F} \triangle \mathrm{FS}$ & Yes & 17 & 1.33 & 0.78 & .19 & $1+00$ & 115 & 0110 & & \\
\hline FAFS & $\mathrm{No}$ & 100 & 1.66 & 0.79 & .08 & -1.598 & 115 & 0.113 & & \\
\hline
\end{tabular}

Table-9. Results of independent samples t test to determine whether the parents' attention levels differed according to reactions of their children when they are not allowed to use technological tools.

\begin{tabular}{|c|c|c|c|c|c|c|c|c|c|c|}
\hline \multirow[t]{2}{*}{ Factors } & \multirow[t]{2}{*}{ Groups } & \multirow[t]{2}{*}{$\boldsymbol{N}$} & \multirow[t]{2}{*}{$\overline{\bar{X}}$} & \multirow[t]{2}{*}{ SS } & \multirow[t]{2}{*}{$\operatorname{Sh}_{\overline{\mathrm{X}}}$} & \multicolumn{3}{|c|}{$t$ test } & \multirow[t]{2}{*}{ Difference } & \multirow{2}{*}{$\begin{array}{l}\text { Effect size } \\
\text { (Cohen's } d)\end{array}$} \\
\hline & & & & & & $t$ & $s d$ & $p$ & & \\
\hline \multirow{2}{*}{ MAFC } & Positive & 60 & 3.54 & 0.32 & 0.04 & \multirow{2}{*}{1.195} & \multirow{2}{*}{115} & \multirow{2}{*}{0.235} & & \\
\hline & Negative & 57 & 3.47 & 0.37 & 0.05 & & & & & \\
\hline MAFBD & Negative & 57 & 3.37 & 0.46 & 0.06 & 1.632 & 115 & 0.105 & & \\
\hline \multirow{2}{*}{ MAFS } & Positive & 60 & 2.54 & 0.80 & 0.10 & \multirow{2}{*}{1.135} & \multirow{2}{*}{115} & \multirow{2}{*}{0.259} & & \\
\hline & Negative & 57 & 2.38 & 0.77 & 0.10 & & & & & \\
\hline \multirow{2}{*}{ FAFBD } & Positive & 60 & 3.08 & 0.67 & 0.09 & \multirow{2}{*}{2.627} & \multirow{2}{*}{115} & \multirow{2}{*}{0.010} & \multirow{2}{*}{ Positive $>$ Negative } & \multirow{2}{*}{.48} \\
\hline & Negative & 57 & 2.75 & 0.70 & 0.09 & & & & & \\
\hline \multirow{2}{*}{ FAFC } & Positive & 60 & 3.26 & 0.57 & 0.07 & \multirow{2}{*}{3.173} & \multirow{2}{*}{115} & \multirow{2}{*}{0.002} & \multirow{2}{*}{ Positive $>$ Negative } & \\
\hline & Negative & 57 & 2.90 & 0.65 & 0.09 & & & & & .58 \\
\hline FAFS & Positive & 60 & 1.76 & 0.75 & 0.10 & 00 & 115 & $0 \Omega 30$ & Positive $>$ Negative & .39 \\
\hline
\end{tabular}


Table-10. Results of correlation analysis between attentions and independent variables.

\begin{tabular}{c|c|c|c|c|c|c|c|c|c|c}
\hline Factors & $\mathbf{1}$ & $\mathbf{2}$ & $\mathbf{3}$ & $\mathbf{4}$ & $\mathbf{5}$ & $\mathbf{6}$ & $\mathbf{7}$ & $\mathbf{S 3}$ & $\mathbf{S 5}$ & $\mathbf{S 8}$ \\
\hline 1-MAFC & 1.00 & $.672^{* *}$ & $.379^{* *}$ & $.430^{* *}$ & $.300^{* *}$ & $.381^{* *}$ & 0.14 & $-.217^{*}$ & -.031 & -.111 \\
\hline 2-MAFBD & & 1 & $.405^{* *}$ & $.350^{* *}$ & $.369^{* *}$ & $.403^{* *}$ & $.300^{* *}$ & $-.226^{*}$ & .023 & -.150 \\
\hline 3-MAFS & & & 1 & $.212^{*}$ & $.188^{*}$ & $.232^{*}$ & $.292^{* *}$ & -.180 & .097 & -.105 \\
\hline 4-MAFII & & & & 1 & $.209^{*}$ & $.301^{* *}$ & $.248^{* *}$ & -.098 & -.103 & -.140 \\
\hline 5-FAFBD & & & & & 1 & $.814^{* *}$ & $.652^{* *}$ & -.002 & $.192^{*}$ & $-.238^{* *}$ \\
\hline 6-FAFC & & & & & & 1 & $.634^{* *}$ & .017 & $.214^{*}$ & $-.284^{* *}$ \\
\hline 7-FAFS & & & & & & & 1 & -.068 & .147 & $-.201^{*}$ \\
\hline S3 & & & & & & & & & -.158 & .020 \\
\hline S5 & & & & & & & & & & 1 \\
\hline S8 & & & & & & & & & & $-.229^{*}$ \\
\hline
\end{tabular}

Fathers' level of attention for behavior development and fathers' level of attention for control were linearly related to mothers and fathers' other attention levels and s5 (behavior score and no option); and were inversely related to s8. The fathers' attention for school was linearly related to all mothers' attention levels, except for the mothers' attention for control, and fathers' other attention levels; and was inversely related to s8 (behavior score and negative option- as score increases, negative behavior decreases). There was an inverse relationship between s5 and s8 (as no increases, negative behavior decreases).

Table-11. Effect size reference range.

\begin{tabular}{c|c|c}
\hline Effect size & d & Reference \\
\hline Very small & 0.01 & Sawilowsky (2009) \\
\hline Small & 0.20 & Cohen (1988) \\
\hline Medium & 0.50 & Cohen (1988) \\
\hline Large & 0.80 & Sawilowsky (2009) \\
\hline Very large & 1.20 & Sawilowsky (2009) \\
\hline Huge & 2.0 &
\end{tabular}

\section{Discussion, Conclusion and Suggestions}

The study was carried out with the participation of 117 children and their parents in order to determine the technology usage of children between the ages of 4-6 and to compare the parents' attention for their children. In line with the findings of the research, the following conclusions were reached.

While the parents' attention for control of the child was high, their attention for behavior development was low and their attention for school was even lower. While under the attention for control, there are characteristics such as the child's readiness to school, controlling his homework, attention to the child's appearance; under the attention for behavior development, the recognition and support of the child's abilities and competences take place. The attention for school refers to the school cooperation and parents involvement. This result of the study can be interpreted as parents are insufficient in recognizing and encouraging their children, cooperating with the school, and showing participation, despite the fact that they show attention for mostly controlling their children.

Parents' beliefs about their children's behaviors shape discipline practices, to what extent autonomy is supported, and their expectations based on children's age. School support and family participation are indisputably important and necessary in the realization of parents' expectations about their children (Rogoff, 1993; Harris and Goodall, 2006). The reason why parents' attention for school is low may be due to many variables that determine the relationship between school and family. In his study, Georgiou (1996) examined the variables that affect academic achievement and concluded that there is no relationship between the academic achievements of children coming from the high control families and parents' high control; and that these families are insufficient in terms of participation and cooperation with school. This result shows that attention for control does not affect academic achievement positively. In this study, despite the high attention for control, it was found that technology usage of children was high. From this point of view, it can be said that parents' attention for control does not have a positive effect on the duration of technology usage of children as well as academic success.

As for the attention for behavior development, Epstein states that if parents inform their children, encourage them, become aware of what they are doing, and take care of them; children at all levels will be better in their academic studies, their attitudes towards school will be more positive, they will have higher expectations, and they will exhibit positive behaviors (Georgiou and Tourva, 2007).

As a result of the present study, it was found that the parents' level of attention for their children differed according to whether children use technological tools while eating. It is known that the support of the father in the care, protection and education process of the child in early childhood has positive effects on the development of the child (Yogman and Garfield, 2016). Pancsofar and Vernon-Feagans (2006) emphasized that father-child communication is an important and unique predictor for advanced language development of children, and that while the mothers' adapt to the vocabulary that the child knows during communication with the child, fathers' use of new words positively affects the language development of the child.

It is an expected result of the study that fathers of children who do not use technological tools while eating show high attention for behavior development and control. This can be interpreted as the fact that fathers are aware of the possible harm of using technological tools while eating; therefore, they keep their attention high for behavior development and control. In studies supporting the results of this research, it has been reported that watching television, one of the use of technological tools, causes disruption of the satiety mechanism in the brain with the effect of various distracting mechanisms and as a result of this, the individual's food consumption increases (Chaput et al., 2011; Pearson and Biddle, 2011). In addition, 99\% of the fathers in the research group are employed. The fact that these fathers are working reduces the number of meals they are having with the children, and the fact that the fathers having fewer meals with their children may be the reason for the fathers' effective use of their 
attention for behavior development and control. The fact that $72 \%$ of the mothers in the study group did not work supports this interpretation.

Parents' level of attention for their children was found to differ according to the reaction of children when using technological tools was not allowed. This can be interpreted as fathers' attention for behavior development, control, and school increases; children give positive responses. In addition, it can be said that children are more willing to follow the instructions given by their fathers because almost all of the fathers in the research group spend less time with their children during the day due to their work. Today, as children begin to use media and technology at an early age, parents are expected to consider and mediate the value of media and technology for the development of their children (American Academy of Pediatrics Council on Communications and Media, 2001;2011). Parental mediation or guidance varies according to the child's age and technological opportunities. Parents become more controlling and restrictive as the age of the child grows in the guidance process for 0-8 years old children (Nikken and Jansz, 2013).

Many studies show that the use of technology in preschool education positively affects children's learning and increases their motivation (Huffstetter et al., 2010; Wolgemuth et al., 2011; Cakıroğlu and Taşkın, 2016; KocamanKaroglu, 2016). On the other hand, the use of computer and television in preschool children will be beneficial and appropriate as long as they are under the supervision of parents, but it shows that interaction with technology adversely affects the developmental characteristics of the child and learns negative attitudes and behaviors outside the parental control (Güngör, 2014). When the other research results are examined, it is emphasized that parental supervision and control is very important in order to increase the positive effects of smart devices on the parentchild relationship (Livingstone and Helsper, 2008; Rosen et al., 2008).

Based on the results of the research, the following suggestions were included. In order to increase the parents' attention for school, effective participation activities can be carried out through school-family cooperation. It is recommended that family education seminars be organized for parents to act together and show common attitudes toward attention for control. Preschool children can be given awareness training on the effective use of technology (time, place, program, tool etc.). According to the results of this study, it is seen that the rate of families with one or two children is $60 \%$. Since the research that will be conducted on families with many children may present different results, groups with different demographics can be studied.

\section{References}

Akkoyunlu, B. and B. Tugrul, 2002. The effects of technological interactions of preschool children in home life on computer literacy. Hacettepe University Journal of the Faculty of Education, 23(23): 12-21.

American Academy of Pediatrics Council on Communications and Media, 2001. Policy statement: Sexuality, contraception, and the media. Pediatrics, 126(3): 576-582.

AAPCCM, 2011. Policy statement: Media use by children younger than 2 years. Pediatrics, 128(5): 1040-1045.

Anderson, K.J. and K.M. Minke, 2007. Parent involvement in education: Toward an understanding of parents' decision making. The Journal of Educational Research, 100(5): 311-323.Available at: https://doi.org/10.3200/joer.100.5.311-323.

Berthelsen, D. and S. Walker, 2008. Parent involvement in their children's educations. Family Matters, 16(79): 34-41.

Büyüköztürk, Ş., 2006. Manual of data analysis for social sciences. Ankara: Pegem A Publishing.

Büyüköztürk, Ş., K.E. Çakmak, Ö.E. Akgün, Ş. Karadeniz and F.V. Demirel, 2012. Scientific research methods. 12th Edn., Ankara: Pegem Academy.

Cakıroğlu, Ü. and N. Taşkın, 2016. Teaching numbers to preschool students with interactive multimedia: An experimental study. Journal of Cukurova University Faculty of Education, 45(1): 1-22.

Campbell, J., C. Connolly and F. Mandel, 1986. Parental influence of Greek parents on gifted and normal elementary school children. Paper Presented at the Greek American Behavioral Sciences Institute Conference, New York.

Chaput, J.-P., L. Klingenberg, A. Astrup and A.M. Sjödin, 2011. Modern sedentary activities promote overconsumption of food in our current obesogenic environment. Obesity Reviews, 12(5): e12-e20.Available at: https://doi.org/10.1111/j.1467-789x.2010.00772.x.

Chaudron, S., M.E. Beutel, M. Černikova, N.V. Donoso, M. Dreier, F.W. B. and K. Wölfling, 2015. Young children (0-8) and digital technology: A qualitative exploratory study across seven countries. Available from http://publications.jrc.ec.europa.eu/repository/handle/JRC93239.

Cohen, J., 1988. Statistical power analysis for the behavioral sciences. New York: Routledge.

Epstein, J.L., 1990. School and family connections: Theory, research, and implications for integrating sociologies of education and family. Marriage \& Family Review, 15(1-2): 99-126.Available at: https://doi.org/10.1300/j002v15no1_06.

Fan, X., 2001. Parental involvement and students' academic achievement: A growth modeling analysis. The Journal of Experimental Education, 70(1): 27-61.Available at: https://doi.org/10.1080/00220970109599497.

Flouri, E. and A. Buchanan, 2004. Early father's and mother's involvement and child's later educational outcomes. British Journal of Educational Psychology, 74(2): 141-153.Available at: https://doi.org/10.1348/000709904773839806.

Georgiou, S.N., 1996. Parental involvement: Definition and outcomes. Social Psychology of Education, 1(3): 189-209.Available at: https://doi.org/10.1007/bfo2339890.

Georgiou, S.N. and A. Tourva, 2007. Parental attributions and parental involvement. Social Psychology of Education, 10(4): 473482.Available at: https://doi.org/10.1007/s11218-007-9029-8.

Green, C.L. and K.V. Hoover-Dempsey, 2007. Why do parents homeschool? A systematic examination of parental involvement. Education and Urban Society, 39(2): 264-285.Available at: https://doi.org/10.1177/0013124506294862.

Greenwood, G.E. and C.W. Hickman, 1991. Research and practice in parent involvement: Implications for teacher education. The Elementary School Journal, 91(3): 279-288.Available at: https://doi.org/10.1086/461655.

Güngör, M., 2014. Pre school children's watching television habits and parental attitudes. Mustafa Kemal University Journal of Graduate School of Social Sciences, $11(28): 199-216$.

Harris, A. and J. Goodall, 2006. Parental involvement in education: An overview of the literature. United Kindon: SSAT

Henderson, A.T. and N. Berla, 1994. A new generation of evidence: The family is critical to student achievement., Columbia, MD: National Committee for Citizens in Education.

Hong, S. and H.-Z. Ho, 2005. Direct and indirect longitudinal effects of parental involvement on student achievement. Journal of Educational Psychology, 97(1): 32-42.Available at: https://doi.org/10.1037/0022-0663.97.1.32.

Hoover-Dempsey, K.V. and H.M. Sandler, 1997. Why do parents become involved in their children's education? Review of Educational Research, 67(1): 3-42.Available at: https://doi.org/10.3102/00346543067001003.

Huffstetter, M., J.R. King, A.J. Onwuegbuzie, J.J. Schneider and K.A. Powell-Smith, 2010. Effects of a computer-based early reading program on the early reading and oral language skills of at-risk preschool children. Journal of Education for Students Placed at Risk, 15(4): 279-298.Available at: https://doi.org/10.1080/10824669.2010.532415.

Jeynes, W.H., 2007. The relationship between parental involvement and urban secondary school student academic achievement: A metaanalysis. Urban Education, 42(1): 82-1 10.Available at: https://doi.org/10.1177/0042085906293818.

Jeynes, W.H., 2011. Parental involvement research: Moving to the next level. The School Community Journal, 21 (1): 9-18.

Karasar, N., 2005. Scientific research and methodology. 15th Edn., Ankara: Nobel Publication Distribution. 
Kocaman-Karoglu, A., 2016. Teachers' opinions on digital storytelling in preschool education. Turkish Online Journal of Qualitative Inquiry, $7(1): 175-205$.

Livingstone, S. and E.J. Helsper, 2008. Parental mediation of children's internet use. Journal of Broadcasting \& Electronic Media, 52(4): 581 599.

Nikken, P. and J. Jansz, 2013. Developing scales to measure parental mediation of young children's internet use. Learning Media and Technology, 39(2): 250-266.

Pancsofar, N. and L. Vernon-Feagans, 2006. Mother and father language input to young children: Contributions to later language development. Journal of Applied Developmental Psychology, 27(6): 571-587.Available at: https://doi.org/10.1016/j.appdev.2006.08.003.

Pearson, N. and S.J. Biddle, 2011. Sedentary behavior and dietary intake in children, adolescents, and adults: A systematic review. American Journal of Preventive Medicine, 41(2): 178-188.Available at: https://doi.org/10.1016/j.amepre.2011.05.002.

Rasmussen, E.R.F., 2017. Screen time and kids: Insights from a new report. Available from https://www.pbs.org/parents/authors/ericrasmussen-phd.

Rogoff, B., 1993. The cultural nature of human development. NY: Oxford University Press.

Rosen, L.D., N.A. Cheever and L.M. Carrier, 2008. The association of parenting style and child age with parental limit setting and adolescent myspace behavior. Journal of Applied Developmental Psychology, 29(6): 459-471.Available at: https://doi.org/10.1016/j.appdev.2008.07.005.

Sawilowsky, S., 2009. New effect size rules of thumb. Journal of Modern Applied Statistical Methods, 8(2): 597-599.Available at: https://doi.org/10.22237/jmasm/1257035100.

Shiffman, C.D., 2013. The juggling act: Navigating parent involvement in the welfare reform era. Educational Policy, 27(1): 64-91.Available at: https://doi.org/10.1177/0895904811429292.

Smith, J., P. Wohlstetter, C.A. Kuzin and D.K. Pedro, 2011. Parent involvement in urban charter schools: New strategies for increasing participation. School Community Journal, 21(1): 71-94.

Steinhoff, A., 2016. The use of technology in early childhood classrooms. Available from https://novakdjokovicfoundation.org/usetechnology-early-childhood-classrooms/.

Sucuoglu, H., N. Ozkal, D.V. Yildiz and C. Guzeller, 2015. Parental interest scale for child development. Abant İzzet Baysal University Faculty of Education Journal, 15(1): 242-263.

Wolgemuth, J., R. Savage, J. Helmer, C. Bottrell, T. Lea, H. Harper, K. Halkıtıs and P. Abramı, 2011 . Using computer-based instruction to improve indigenous early literacy in Northern Australia: A quasi-experimental study. Australasian Journal of Educational Technology, 27(4): 727-750.Available at: https://doi.org/10.14742/ajet.947.

Yogman, M. and C. Garfield, 2016. Fathers' roles in the care and development of their children: The role of pediatricians. Pediatrics, 138(1): $1-17$. 